\title{
Evaluation of PV microgeneration systems and tariffs management on the energy efficiency of service buildings
}

\author{
J. Baptista ${ }^{1,2}$, G. Sequeira ${ }^{1}$ and E. J. Solteiro Pires ${ }^{1,2}$ \\ ${ }^{1}$ Department of Engineering \\ ${ }^{2}$ INESCTEC UTAD Pole \\ University of Trás-os-Montes and Alto Douro \\ Quinta de Prados - Vila Real, 5001-801 Vila Real, Portugal \\ baptista@utad.pt,al65370@utad.eu, epires@utad.pt
}

\begin{abstract}
The buildings' energy consumption increasing requires solutions to improve their energy efficiency, thus reducing the electricity bill's associated costs. This paper aims to study the load profiles of a service building and its optimization to reduce the costs related to electricity consumption. The electrical load profiles are analyzed, and the electrical equipment and its consumption are characterized. Moreover, to increase energy efficiency and reduce energy costs, a renewable energy system based on photovoltaic panels is sized and integrated into the building. The analysis of the building's consumption profiles allowed the PV system's dimensioning to eliminate power peaks, enabling a reduction in the contracted power. The results demonstrate the effectiveness of the proposed solution, resulting in a reduction of the electricity bill.
\end{abstract}

Key words. Load profile, energy efficiency, renewable energy, Building-Integrated Photovoltaic Systems.

\section{Introduction}

The constant technological development in which society current situation implies an increase in energy consumption, and consequently, the associated costs. Thus, the search for solutions that improve energy efficiency has been a target of great focus to promote the reduction of the electricity bill and the use of fossils fuels. Buildings are responsible for $30 \%$ of final energy consumption in Portugal, a trend that has been increasing in recent years, according to DGEG (Portuguese Directorate of Energy and Geology) [1]. Thus, it is essential to find solutions to increase energy efficiency, namely energy consumption. Service buildings, in particular offices, are a target in the implementation of such measures, because most consumptions are during the daytime periods where electricity tariffs are higher. Before applying energy efficiency measures, the space must be classified as to its use. This depends on three factors: occupation and occupation context, environmental sensitivity, and energy sensitivity. Occupation and occupation context define the number of people and their activity within the location in question. Environmental sensitivity refers to factors such as temperature, and other variables to which a building's given area is subject. Energy sensitivity is obtained by accounting and monitoring the consumption of a given area or space in a building, namely the consumption related to ventilation heating and air conditioning (HVAC), lighting, computer equipment's and other deferrable loads [2]. Thus, the most used solutions to reduce energy waste go through the buildings thermal insulation improvement, HVAC control, load scheduling, lightning control, renewable energies systems integration, energy storage system and the applications of demand-side management programs.

Among the solutions presented, the integration of renewable energies systems will be the one that this paper will focus on. In the specific case, a PV system will be designed in order to limit the peak power consumption of the building under study. This work also studies the load diagrams associated with a service building, and assess the impact of incorporation PV systems in the electricity bill. Several authors have studied the topic of energy efficiency in buildings using different methodologies. In [3], the implementation of automation systems in buildings, more specifically, HVAC. The obtaining greater energy efficiency of the system to quickly estimate an approximation of the heat storage parameters of buildings. In [4], intelligent controllers are presented to enable user comfort and safety, and better energy efficiency achieved. The use of ICT (Information and Communications Technology) in buildings, intelligent devices ensures user comfort through automatic control of temperature, humidity, and brightness. For user safety, advanced alarm systems are designed to help occupants in emergencies such as earthquakes or fires. Energy efficiency is achieved through intelligent HVAC control, as mentioned in [3]. Authors like [5] study the topic at the building construction aspects, the use of insulating materials, a modified construction methodology, and different architectural techniques. This study proves that using a double wall with insulation, and SCIP (Structural Concrete Insulated Panel) as wall covering can reduce the energy required by the building up to $3 \%$. The BuildingIntegrated Photovoltaic Systems (BIPVS) is a topic addressed by several authors [6-8] focusing on energy generation amount, rated power, efficiency, type, and performance assessment approaches. In a different 
approach, in [9-14], the improvement of energy efficiency is obtained through BIPVS. In [14], the PV system is sized for an NZEB building (Nearly Zero Energy Building).

This paper is organized in five sections, Section 2 introduces the theoretical concepts related to the subject under study and explain the energy efficiency measures used. In the third section the case study is developed where the measures presented in section 2 are applied to increase the building energy efficiency. In section 4 the results are analyzed and discussed. In the last section, the conclusions and perspectives of future work are presented.

\section{Methodology}

Energy efficiency in buildings is a broad topic, ranging from the buildings' construction to the renewable energy systems integration. The approach used to optimize building energy efficiency depends on several factors, such as the type of building, the atmospheric conditions, the location, the number of people and their permanence in the place, and the amount of electrical equipment being used. The integration of renewable energy systems in buildings is an important measure to increase energy efficiency and is increasingly used, with an emphasis on PV systems. The installation of a PV system is most beneficial in a building located in an area with adequate solar irradiance throughout the year. In a building with a PV system integration, it has to be considered that, generally, the sun exposure hours do not match with the periods of greatest power consumption.

For this reason, a possible solution is the use of batteries to store the energy produced by the PV system throughout the day, to then be consumed outside working hours. The choice of the appropriate tariff can also be considered an interesting approach to optimize energy efficiency. In a building, choosing a tariff that adjusts to the fluctuations in energy consumption throughout the day can considerably impact the electricity bill. In this paper, these two aspects will be studied and analyzed.

\section{A. Photovoltaic systems}

For sizing a PV system, the first step is to calculate the number of panels needed to satisfy the previously defined energy needs, which can be calculated from (1) [15].

$$
N_{m}=\frac{1.2 E_{\text {load }}}{E_{\text {daily }} \cdot N D C L}
$$

Where $N_{m}$ is the number of panels, $E_{\text {load }}$ is the building's daily energy requirement and $N D C L$ is the number of days of a consumption cycle (usually one day if consumption is daily). For this calculation, it is necessary to determine some parameters not provided by the manufacturer, such as the cell temperature value, given by (2).

$$
\theta_{c}=\theta_{a}+\frac{G(N O C T-20)}{800}
$$

Where:

$\theta_{a}-$ Cell temperature $\left({ }^{\circ} \mathrm{C}\right)$;

$\theta_{c}-$ Air temperature $\left({ }^{\circ} \mathrm{C}\right)$;

$G$ - Solar radiation $\left(\mathrm{W} / \mathrm{m}^{2}\right)$;
NOCT - Nominal Operating Cell Temperature $\left({ }^{\circ} \mathrm{C}\right)$, provided by the manufacturer. NOCT is defined as the temperature reached by open-circuited cells in a module under the standard test conditions.

The voltage and current corresponding to the maximum power are obtained by (3) and (4).

$$
\begin{gathered}
I_{t \max }=I_{\max }\left(25^{\circ} \mathrm{O}\right) \cdot\left[1+\alpha\left(T_{c}-25\right)\right] \\
V_{t \max }=V_{\max }\left(25^{\circ} \mathrm{C}\right)+\beta\left(T_{c}-25\right)
\end{gathered}
$$

Where:

$I_{\text {tmax }}$ - Temperature-corrected maximum current (A);

$V_{\text {tmax }}$ - Temperature-corrected maximum voltage $(\mathrm{V})$;

$\alpha$ - Current temperature coefficient, $\mathrm{mA} /{ }^{\circ} \mathrm{C}$;

$\beta$ - Voltage temperature coefficient, $\mathrm{V} /{ }^{\circ} \mathrm{C}$.

Therefore, the total energy produced by a module is obtained by (5). For this dimensioning, to make the system sustainable throughout the year, it is usual to use irradiance and temperature data for the most unfavourable months (December or January for European countries).

$$
E_{\text {daily }}=H P D \cdot I_{\text {tmax }} \cdot V_{\text {tmax }} \cdot \eta
$$

Where:

$H P D$ - Number of hours of the day with $1000 \mathrm{~W} / \mathrm{m}^{2}$ irradiance;

$\eta$ - Inverter efficiency.

\section{B. Electricity tariffs}

Regulated electricity tariff prices are defined annually. In the Portuguese case by the Portuguese Energy Services Regulatory Authority (ERSE), for a period coinciding with the calendar year (January to December) [16]. The regulated tariffs, which reflect the costs of regulated activities and for which ERSE defines the amount of permitted income, are reflected in all consumers' bills, both in the regulated and liberalized markets. The methodology for calculating the amount of allowed income for each regulated activity and the structure of regulated tariffs are defined in the Tariff Regulation, approved by ERSE. In Portugal, there is currently a wide range of electricity tariffs being offered for low voltage consumers: Simple/Fixed tariffs and Time of Use tariffs (Bi-Hourly and Tri-Hourly) where the unit price differs accordingly to the day time. The simple tariff has the same price at all times of the day. The time of use tariffs has different prices to encourage consumers to use electricity when more is available cheaply. This system can support a more flexible and sustainable electricity system. I bihourly tariff, the electricity price is reduced at night and the weekend and higher in remaining periods. The Trihourly tariff has three different prices throughout the day. The Bi and Tri hourly tariff also depends on the season of the year, and summer and winter periods. In this scenario, the tariff choice that best suits the electricity consumption can considerably reduce the electricity bill.

\section{Case Study}

In this chapter will be studied, an office building located in the city of Vila Real in Portugal, whose load profiles were based on the reference [17]. The energy 
consumptions of the building vary according to the weekly periods. Figure 1 and Figure 2 represent a simplified load profile corresponding to the energy consumption on a typical weekday and weekend day.

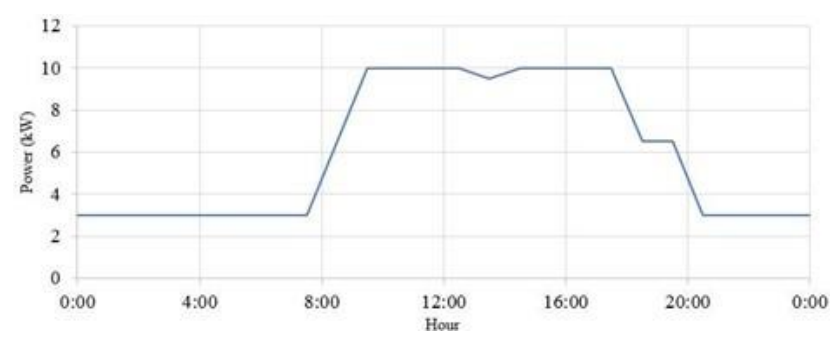

Fig.1. Load profile on a typical weekday.

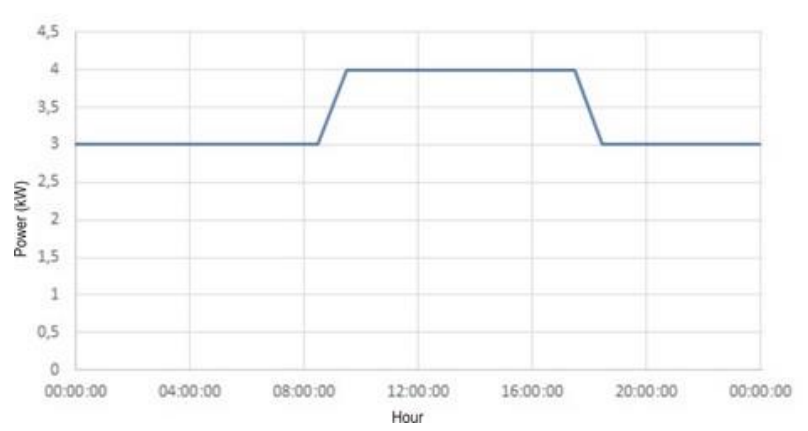

Fig.2. Load profile on a typical weekend day.

Table I characterizes the main loads present in the building. The quantities and the respective power consumption are displayed during a weekday and on the weekend day. Two possible exploration scenarios will be studied. In the first scenario, it will be considered that all the power comes from the power grid, with the possibility of managing the tariffs, while in the second scenario, the integration of a PV system in the building is considered.

Table I. - Characterization of the loads installed in the office [17].

\begin{tabular}{lccc}
\hline Equipment type & $\begin{array}{c}\text { Profile } \\
\text { weekday (Wh) }\end{array}$ & $\begin{array}{c}\text { Profile } \\
\text { weekend day } \\
(\text { Wh })\end{array}$ & $\begin{array}{c}\text { Quantity of } \\
\text { equipment's }\end{array}$ \\
\hline Laptop computer & 512 & 240 & 99 \\
\hline $\begin{array}{l}\text { High-end } \\
\text { desktop computer }\end{array}$ & 180 & 78 & 19 \\
\hline $\begin{array}{l}\text { Low-end } \\
\text { desktop computer }\end{array}$ & 120 & 52 & 22 \\
\hline 19" LCD screen & 120 & 52 & 128 \\
\hline 21'LCD screen & 60 & 26 & 22 \\
\hline Large photocopier & 60 & 26 & 4 \\
\hline Plotter & 60 & 26 & 1 \\
\hline Coffee machine & 40 & 16 & 2 \\
\hline Fridge & 20 & 8 & \\
\hline
\end{tabular}

\section{A. Scenario 1: All power comes from the power grid}

In this scenario, it's considered that the office building is supplied exclusively by the power grid, considering the tariffs management according to the tariffs regimes shown in Table II. Considering the load profiles of Figure 1 and Figure 2 and the various possible tariff regimes, monthly energy consumption and costs for the three tariff regimes available on the market were calculated. By analyzing the weekday load diagram, it is verified that the peak power is greater than $10 \mathrm{~kW}$, so the level of contracted power considered was $13.8 \mathrm{kVA}$ so that it remains with a margin allowing for possible fluctuations in the load profile. To obtain the yearly energy costs, we start by calculating the daily costs taking into account the different hourly options and the weekly period. Then the monthly energy cost is calculated by adding the respective rate of the contracted power. The electricity consumed monthly throughout the year is shown in the graph in Figure 3, while Table II shows the monthly costs for the different tariff regimes considered.

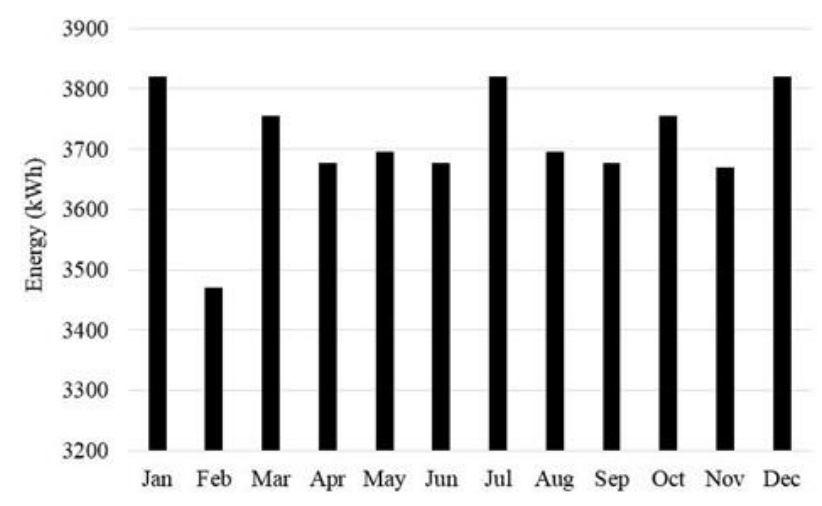

Fig.3. Monthly electricity consumption.

Table II. - Monthly costs for the different tariff regimes (13.8kVA).

\begin{tabular}{lccc}
\hline Month & Fixed $(€)$ & $\begin{array}{c}\text { Tariffs } \\
\text { Bi-Hourly }(€)\end{array}$ & Tri-Hourly $(€)$ \\
\hline January & 608 & 649 & 655 \\
\hline February & 554 & 583,5 & 589 \\
\hline March & 598 & 574 & 579 \\
\hline April & 586 & 660 & 673 \\
\hline May & 589 & 620 & 609 \\
\hline June & 586 & 626 & 615 \\
\hline July & 608 & 651 & 640 \\
\hline August & 589 & 620 & 609 \\
\hline September & 586 & 626 & 615 \\
\hline October & 598 & 493 & 484 \\
\hline November & 585 & 750 & 758 \\
\hline December & 608 & 649 & 655 \\
Total yearly & 7095 & 7501,5 & 7481 \\
\hline
\end{tabular}

B. Scenario 2: All power comes from the power grid and PV system

In this paper, a peak shaving approach was used that allows reducing the contracted power. The aim is to reduce the contracted power to $6.9 \mathrm{kVA}$, which will create a cut in the building's load profile for weekdays, as shown in Figure 4. Thus, a considerable part of the energy required (shaded area) will come from the PV system. In this scenario, the daily energy that comes from the grid when the contracted decay to $6.9 \mathrm{kVA}$ is $116 \mathrm{kWh}$. The PV system will be sized to produce the remaining energy, which corresponds to $28 \mathrm{kWh}$. This energy requirement corresponds to the shaded area of the load diagram represented in the Figure 4. With this change regarding the weekday load profile that will be ensured by the power grid is shown in Figure 5. 


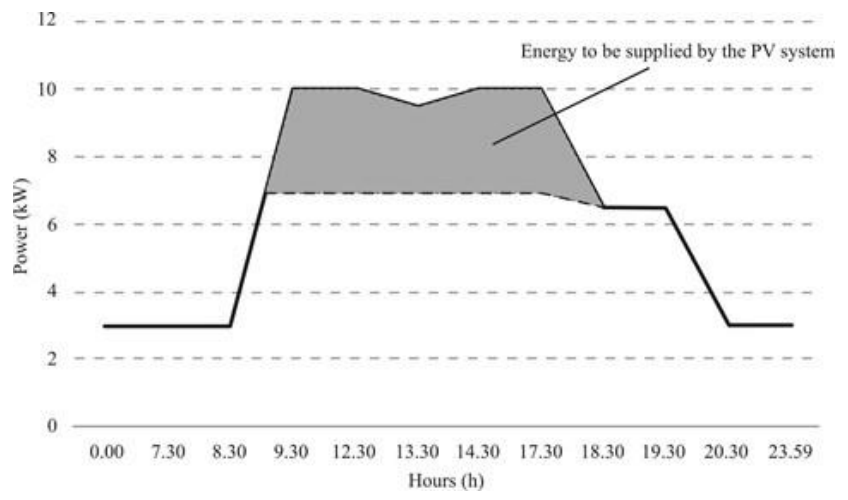

Fig.4. Energy to be supplied by the PV system (peak shaving).

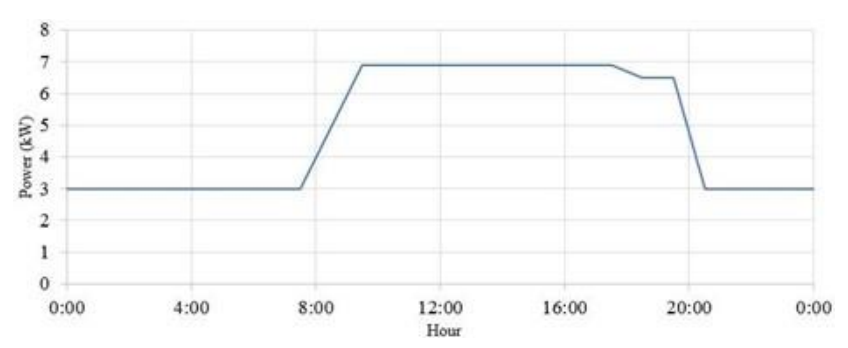

Fig.5. Weekday load profile with the peak power cut.

With the new weekday load profile of Figure 5, all the previous parameters are recalculated to verify the impact that the integration of the PV system had on the energy yearly bill. The results are shown in Table III.

Table III. - Monthly costs for the different tariff regimes (6.9kVA).

\begin{tabular}{lccc}
\hline Month & Fixed $(€)$ & $\begin{array}{c}\text { Tariffs } \\
\text { Bi-Hourly }(€)\end{array}$ & Tri-Hourly $(€)$ \\
\hline January & 519 & 540 & 540 \\
\hline February & 477 & 489 & 489 \\
\hline March & 514 & 479 & 479 \\
\hline April & 501 & 577 & 570 \\
\hline May & 508 & 516 & 510 \\
\hline June & 501 & 518 & 512 \\
\hline July & 519 & 538 & 532 \\
\hline August & 508 & 516 & 510 \\
\hline September & 501 & 518 & 512 \\
\hline October & 514 & 409 & 404 \\
\hline November & 495 & 627 & 627 \\
\hline December & 519 & 540 & 540 \\
Total yearly & 6076 & 6267 & 6225 \\
\hline
\end{tabular}

After knowing the energy needs that the PV system has to guarantee and knowing the building's location, the next step is to design and size the solar electrical system, determining the correct size of the PV array. The PV system energy balance is obtained using the local climatic data, namely the irradiance and the air temperature. These data were obtained from the European Commission PVGIS Database [18]. System sizing starts with determining the total array power output needed to supply the building, which, as previously mentioned, will be $28 \mathrm{kWh}$ per day. After consulting several manufactures, the PV solar panel chosen for the PV system was the Panasonic N340, whose main characteristics are shown in Table IV.
Table IV. - Panasonic N340 technical specifications.

\begin{tabular}{ll}
\hline Model & VBHN340SA17 \\
\hline Rated Power $\left(P_{\max }\right)$ & $340 \mathrm{~W}$ \\
\hline Maximum Power Voltage $\left(V_{\max }\right)$ & $59.7 \mathrm{~V}$ \\
\hline Maximum Power Current $\left(l_{\max }\right)$ & $5.70 \mathrm{~A}$ \\
\hline Open Circuit Voltage $\left(V_{o c}\right)$ & $71.3 \mathrm{~V}$ \\
\hline Short Circuit Current $\left(I_{s c}\right)$ & $6.13 \mathrm{~A}$ \\
\hline Temperature Coefficient $\left(P_{\max }\right)$ & $-0.258 \% /{ }^{\circ} \mathrm{C}$ \\
\hline Temperature Coefficient $\left(V_{o c}\right)$ & $-0.17 \mathrm{~V} /{ }^{\circ} \mathrm{C}$ \\
\hline Temperature Coefficient $\left(l_{s c}\right)$ & $3.34 \mathrm{~mA} /{ }^{\circ} \mathrm{C}$ \\
\hline NOCT & $44.0{ }^{\circ} \mathrm{C}$ \\
\hline Cell Efficiency & $22.85 \%$ \\
\hline Module Efficiency & $20.3 \%$ \\
\hline
\end{tabular}

The temperature and irradiance of the worst month were considered, i. e., December. The voltage and current corresponding to the maximum power are obtained by the equations (3) and (4). Replacing by the real values:

$$
\begin{gathered}
I_{t \max }=5.7 \cdot[1+0.00334(12-25)]=5.45 \mathrm{~A} \\
V_{\text {tmax }}=59.7-0.17(12-25)=61.91 \mathrm{~V}
\end{gathered}
$$

Therefore, the total energy produced by a single panel by equation (5) is:

$$
E_{\text {daily }}=\frac{101.6 \times 24}{1000} \cdot 5.45 \cdot 61.91 \cdot 0.95=823 \mathrm{Wh}
$$

Equation (1) is used to calculate the number of panels needed to satisfy the previously defined energy needs. Considering one for the consumption cycle, the number of panels is:

$$
N_{m}=\frac{1.2 \times 28000}{823 \times 1}=40.8
$$

Therefore, to satisfy the daily needs of $28 \mathrm{kWh}, 41$ panels are required. The system was sized for December. Thus, the energy produced in the remaining months of the year will exceed the imposed needs. Table V shows the energy produced for all months of the year, where this can be seen.

Table V. - Daily and monthly energy produced by the PV system.

\begin{tabular}{lrcc}
\hline Meses & $\begin{array}{c}\mathrm{G} \\
\left(\mathrm{W} / \mathrm{m}^{2}\right)\end{array}$ & $\begin{array}{c}\text { Edaily (41 panels) } \\
(\mathrm{Wh})\end{array}$ & $\begin{array}{c}E_{\text {monthly }} \text { (41 panels) } \\
(\mathrm{Wh})\end{array}$ \\
\hline Jan & 132.0 & 35983.75 & 1115496.24 \\
Fev & 152.6 & 41774.59 & 1169688.63 \\
Mar & 211.3 & 58185.02 & 1803735.72 \\
Apr & 217.6 & 59759.94 & 1792798.24 \\
May & 240.0 & 65465.20 & 2029421.33 \\
Jun & 262.8 & 70802.23 & 2124066.76 \\
Jul & 269.8 & 72258.46 & 2240012.27 \\
Aug & 273.6 & 73263.02 & 2271153.71 \\
Sep & 238.3 & 64108.31 & 1923249.32 \\
Oct & 183.9 & 49483.38 & 1533984.69 \\
Nov & 127.5 & 34248.69 & 1027460.83 \\
Dec & 101.6 & 27201.45 & 843244.89 \\
\hline
\end{tabular}


The surplus energy produced in the remaining eleven months of the year may be sold to the power grid, taking into account the feed-in tariffs. It was considered that all energy produced by the PV system during the weekend is injected into the grid. Table VI shows the monthly surplus energy that can be injected into the grid and the profits obtained from that sale. The selling price of $30 € / \mathrm{MWh}$ was considered according to the MIBEL spot market (Iberian Electricity Market).

Table VI. - Monthly profits from energy sales.

\begin{tabular}{lcccr}
\hline Month & $\begin{array}{c}E_{\text {monthly }} \\
\text { weekdays } \\
(\text { Wh })\end{array}$ & $\begin{array}{c}E_{\text {monthlv }} \\
\text { weekend } \\
(\text { Wh })\end{array}$ & $\begin{array}{c}\text { Energy } \\
\text { surplus } \\
(\text { Wh })\end{array}$ & $\begin{array}{c}\text { Profit } \\
(€)\end{array}$ \\
\hline Jan & 827626.25 & 287870.00 & 471496.24 & 14.14 \\
Fev & 793717.28 & 375971.34 & 637688.63 & 19.13 \\
Mar & 1280070.51 & 523665.21 & 1187735.72 & 35.63 \\
Apr & 1314718.71 & 478079.53 & 1176798.24 & 35.30 \\
May & 1374769.29 & 654652.04 & 1441421.33 & 43.24 \\
Jun & 1557648.96 & 566417.80 & 1508066.76 & 45.24 \\
Jul & 1661944.59 & 578067.68 & 1596012.27 & 47.88 \\
Aug & 1538523.48 & 732630.23 & 1683153.71 & 50.49 \\
Sep & 1410382.84 & 512866.49 & 1307249.32 & 39.22 \\
Oct & 1088634.29 & 445350.39 & 917984.69 & 27.54 \\
Nov & 719222.58 & 308238.25 & 439460.83 & 13.18 \\
Dec & 625633.30 & 217611.58 & 199244.89 & 5.98 \\
\hline Total & 14192892.1 & 5681420.6 & 12566312.6 & 376.99 \\
\hline
\end{tabular}

\section{Discussion}

This section analyzes the results obtained through the two previous scenarios. In the first scenario, all building energy needs come from the power grid; only the tariffs management was considered. The results illustrated in Table III can concluded that the fixed tariff is the one with the most savings in the electricity bill. This result was expected as most of the building's consumption is during the daytime, so the bi-hourly and tri-hourly tariffs show higher rates in these periods.

In the second scenario, the integration of a PV system into the building was considered. With this solution, part of the energy needs comes from the PV system, reducing the contracted power and the energy purchased from the power grid. Table VII shows the results obtained with this second solution, considering the profit obtained from these two components: the savings verified in the electricity bill due to the energy supplied from the PV system with the reduction in the contracted power and another profit resulting from the sale of the surplus energy produced. Annual savings of $2674.56 €$ is obtained, adding these two tranches.

The graph of Figure 6 shows the monthly evolution of costs for the two scenarios studied. It also shows the profits/savings obtained, taking into account scenario 2 . As can be seen, the profit increases in the summer months due to the PV system higher energy production, thus increasing the use and sale of energy from the PV system to the grid.
Table VII. - Energy Costs and savings for scenario 2.

\begin{tabular}{lcccc}
\hline Month & $\begin{array}{c}\text { Consump. } \\
(\mathrm{kWh})\end{array}$ & $\begin{array}{c}\text { PV Energy } \\
\text { prod. }(\mathrm{kWh})\end{array}$ & $\begin{array}{c}\text { Energy from } \\
\text { grid }(\mathrm{kWh})\end{array}$ & $\begin{array}{c}\text { Savings } \\
(€)\end{array}$ \\
\hline Jan & 3819.51 & 827.63 & 2991.88 & 136.75 \\
Fev & 3469.54 & 793.72 & 2675.82 & 131.52 \\
Mar & 3754.70 & 1280.07 & 2474.63 & 206.56 \\
Apr & 3676.93 & 1314.72 & 2362.21 & 211.91 \\
May & 3696.37 & 1374.77 & 2321.60 & 221.18 \\
Jun & 3676.93 & 1557.65 & 2119.28 & 249.40 \\
Jul & 3819.51 & 1661.94 & 2157.56 & 265.49 \\
Aug & 3696.37 & 1538.52 & 2157.85 & 246.44 \\
Sep & 3676.93 & 1410.38 & 2266.55 & 226.67 \\
Oct & 3754.70 & 1088.63 & 2666.06 & 177.03 \\
Nov & 3670.45 & 719.22 & 2951.22 & 120.03 \\
Dec & 3819.51 & 625.63 & 3193.87 & 105.59 \\
\hline Total & 44531.43 & 14192.89 & 30338.54 & 2298.56 \\
\hline & \multicolumn{5}{c}{} \\
\hline
\end{tabular}

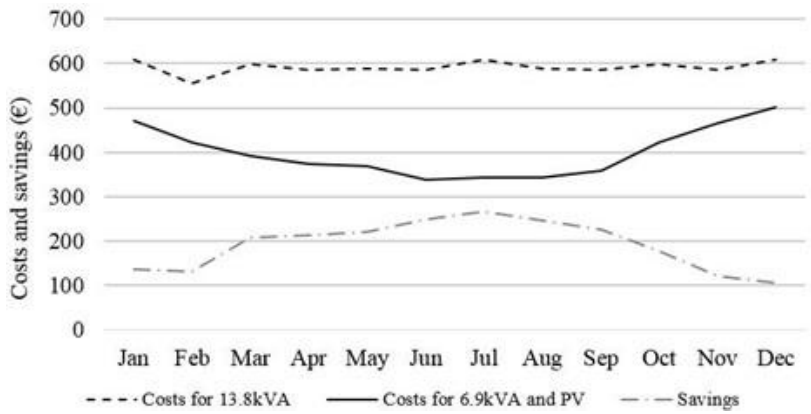

Fig.6. Results comparison between scenario 1 and scenario 2 .

To better understand the feasibility of the investment spent in the PV system, it is essential to know how the initial costs will be amortized over time. One of the main parameters that allows to evaluating this is the knowledge of the payback period. Over the last decade, prices for grid-connected PV systems have decreased significantly. According to [19], the used benchmark CAPEX (capital expenditure or investment) for an installed PV system around $1100 € / \mathrm{kWp}$ for all European countries. In the present study, the PV system consists of 41 panels of 340 $\mathrm{Wp}$, which makes a total installed power of $13940 \mathrm{Wp}$, representing an initial investment of approximately $15345 €$.

To account for the profits from the sale of the produced energy, the average reference tariffs practiced in 2020 were considered for the Price Of Energy (POE), which were around $30 € / \mathrm{MWh}$. This value reflects the average at the liberalized market of the last six years, according to OMIE (Iberian Electric Market Operator). Nevertheless, POE varies considerably every year. In this study, the POE was dynamic over the 25 years considered for the project lifetime, considering the inflation rate of $2 \% / y e a r$. Another parameter to take into account to obtain the net cash flow is the annual Operation and Maintenance Costs (OMC), which were considered to be $1 \%$ of the initial investment updated annually according to the inflation rate.

The return on investment will consider the annual savings in the energy bill plus the profits obtained from the surplus energy sold to the grid (2674.56 $€$ for the first year). As shown in Figure 7, considering the project lifetime of 25 years, the investment will have payback period around 6 
years, which is considered very profitable, for renewable energy projects.

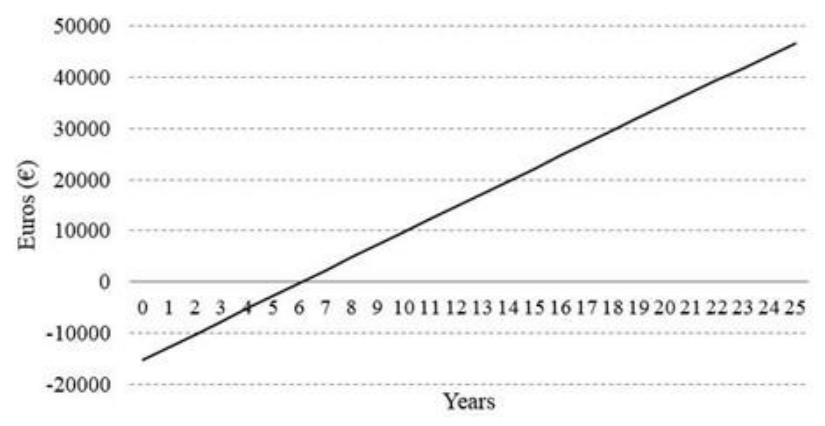

Fig.7. Results comparison between scenario 1 and scenario 2 .

\section{Conclusion}

Increasing the energy efficiency of buildings is a topic that is currently on the agenda of all countries and should be a priority for all citizens. An office building's particular case was studied in this work, where energy consumption is mostly spent during daytime periods. The aim was to improve the building's energy efficiency by managing the electricity tariffs available on the market and, in a second approach, to verify the feasibility of integrating a PV system into the building to supply electricity and sell the surplus to the grid. In the first scenario, it was concluded that the choice of adequate tariff that fits the consumption significantly reduces the annual electricity bill. The second scenario, which concerns integrating a PV system, proved that this is a very profitable solution leading to significant annual bill savings, around $32.5 \%$. Economic analysis has shown that the investment payback is around six years, which denotes the project viability.

\section{Acknowledgement}

This work is financed by National Funds through the Portuguese funding agency, FCT - Fundação para a Ciência e a Tecnologia, within project UIDB/50014/2020.

\section{References}

[1] Direção-Geral de Energia e Geologia. Energy consumption. http://www.dgeg.gov.pt/, 2020.

[2] Weng, T.; Agarwal, Y. From Buildings to Smart Buildings-Sensing and Actuation to Improve Energy Efficiency. IEEE Design Test of Computers 2012, 29, 36-44.

[3] Zucker, G.; Ferhatbegovic, T.; Bruckner, D. Building automation for increased energy efficiency in buildings. 2012 IEEE International Symposium on Industrial Electronics, 2012, pp. 1191-1196.

[4] Sciuto, D.; Nacci, A.A. On How to Design Smart Energy-Efficient Buildings. 2014 12th IEEE International Conference on Embedded and Ubiquitous Computing, 2014, pp. 205-208.

[5] Khaliq, W.; Mansoor, U.B. Energy efficient design and sustainable buildings. 2014 International Conference on Energy Systems and Policies (ICESP), 2014, pp. 1-8.

[6] Biyik, E.; Araz, M.; Hepbasli, A.; Shahrestani, M.; Yao, R.; Shao, L.; Essah, E.; Oliveira, A.; Caño, T.; Rico, E.; Lechón, J.; Andrade, L.; Mendes, A.; Atli, Y. A key review of building integrated photovoltaic (BIPV) systems. Engineering Science and Technology, an International Journal 2017, 20, 833-858.
[7] Mehravaran, A.; Derhem, A.; Nassereddine, M. BuildingIntegrated Photovoltaics (BIPV) for Residential and Industrial Properties. Advances in Science and Engineering Technology International Conferences (ASET), 2019, pp. 1-6.

[8] Fanney, A.; Dougherty, B.P.; Davis, M.W. Performance and characterization of building integrated photovoltaic panels. the Twenty-Ninth IEEE Photovoltaic Specialists Conference, 2002, pp. 1493-1496.

[9] Basir, A.; Siraj, A.S.; Huq, K.R.M. Analysis of building energy efficiency and integration of renewable energy sources. 2015 International Conference on Electrical Engineering and Information Communication Technology (ICEEICT), 2015, pp. 14.

[10] Kinab, E.; Salem, T.; Merhy, G. BIPV building integrated photovoltaic systems in mediterranean climate. International Conference on Renewable Energies for Developing Countries, 2014, pp. 180-185.

[11] Yang Hongxing.; Lou Chengzhi.; Sun Liangliang. Buildingintegrated photovoltaics for maximum power generation. 2008 2nd Electronics System-Integration Technology Conference, 2008, pp. 39-44.

[12] Dimitrova, E.; Dimitrov, V. Integration of a Photovoltaic Plant to a Building Management System. 2019 International Conference on Creative Business for Smart and Sustainable Growth (CREBUS), 2019, pp. 1-4.

[13] Cerón, I.; Caamaño-Martín, E.; JavierNeila, F. 'State-of-theart' of building integrated photovoltaic products. Renewable Energy, 2013, Vol. 58, pp. 127-133.

[14] Tidjani, F.S.; Chandra, A. Integration of renewable energy sources and the utility grid with the Net Zero Energy Building in Republic of Chad. IECON 2012 - 38th Annual Conference on IEEE Industrial Electronics Society, 2012, pp. 1025-1030.

[15] José Baptista.; Raúl Morais. Fundamentos de Energia Solar Fotovoltaica, Vila Real: UTAD; Série Didática, Ciências Aplicadas 383, Edição do Núcleo Editorial e Gráfico dos SDB da UTAD, 2010.

[16] ERSE. Republic Diary, Series I, 2020, number 3.

[17] Menezes, A.C.; Cripps, A.; Buswell, R.A.; Wright, J.; Bouchlaghem, D. Estimating the energy consumption and power demand of small power equipment in office buildings. Energy and Buildings, 2014, Vol. 75, pp. 199-209.

[18] Hub, E.S. Photovoltaic Geographical Information System. https://ec.europa.eu/jrc/en/pvgis, 2020.

[19] Jäger-Waldau, A. PV Status Report 2019, EUR 29938 EN ed.; Publications Office of the European Union, 2019. 